\title{
INVESTASI BAGI HASIL DALAM EKONOMI MIKRO ISLAM
}

\author{
Jahidin \\ Program Pasca Sarjana UIN Sunan Gunung Djati Bandung \\ Jl. A. H. Nasution Nomor 105 Bandung \\ Email: jahidin_ajay@yahoo.co.id
}

\begin{abstract}
Abstrak
Keadilan dan kemaslahatan merupakan dasar dan tujuan dalam sistem ekonomi Islam. Sehingga ekonomi Islam mengajarkan, bahwa dalam menjalin kerja sama dalam kegiatan perekonomian tidak terjadi suatu kesenjangan, seperti halnya tidak ada salah satu pihak yang merasa dirugikan. Oleh karena itu, berkenaan dengan kerja sama dalam kegiatan perekonomian, sistem ekonomi Islam tidak seperti sistem ekonomi konvensional. Hal ini terlihat pada salah satu bentuk kerjasama pemberian modal usaha, di mana sistem ekonomi konvensional menggunakan sistem bunga untuk mendapatkan keuntungan dalam kerja sama tersebut, berbeda dengan sistem ekonomi Islam yang menggunakan sistem bagi hasil untuk mendapatkan keuntungan, sehingga keuntungan yang didapat merupakan keuntungan bersama dan dibagi sesuai denga kesepakatan bersama. Adapun model atau macam-macam investsi bagi hasil dalam ekonomi mikro Islam sangat banyak. Namun secara umum prinsip bagi hasil dalam perbankan syari'ah dapat dilakukan dalam empat akad utama yakni al-musyârakah, al-mudlârabah, al-muzâra'ah, dan al-musâqah. Sungguhpun demikian prinsip yang paling banyak dipakai adalah al-musyârakah dan al-mudlârabah.
\end{abstract}

Kata Kunci:

Bagi Hasil, Mudlarabah, Musyarakah

\section{A. Pendahuluan}

Perekonomian adalah suatu bentuk kegiatan yang tidak dapat dipisahkan dari kehidupan manusia, karena di mana ada manusia maka disitulah akan terjadi kegiatan perekonomian dalam rangka menunjang keberlangsungan kehidupannya. Oleh sebab itu ajaran Islam memberikan landasan-landsan mengenai kegiatan perekonomian yang baik, 
sehingga tercapailalah kehidupan manusia yang makmur, adil dan sejahtera. Oleh karena itu ajaran Islam yang merupakan rahmatan lil alamin dapat terwujud. Salah satu ciri khas dari perekonomian yang berbasis Islam adalah melaksanakan aqidah dan syari'at dalam kegiatan ekonomi dan bisnis bukan hanya sekedar mencari keuntungan dan dapat bertahan hidup, sehingga dalam kegiatan ekonomi Islam aspek agamapun sangat diperhatikan. ${ }^{1}$

Mewujudkan keadilan dan kemaslahatan merupakan dasar dan tujuan dalam sistem ekonomi Islam. Sehingga ekonomi Islam mengajarkan, bahwa dalam menjalin kerja sama dalam kegiatan perekonomian tidak terjadi suatu kesenjangan. Seperti halnya tidak terjadi salah satu pihak yang merasa dirugikan. Oleh karena itu berkenaan dengan kerja sama dalam kegiatan perekonomian, sistem ekonomi Islam tidak seperti sistem ekonomi konvensional. Dimana dalam sistem ekonomi konvensional kerja sama merupakan suatu bentuk perekonomian yang hanya mementingkan dirinya sendiri. Hal ini terlihat pada salah satu bentuk kerja sama pemberian modal usaha. Dimana sistem ekonomi konvensional menggunakan sistem bunga untuk mendapatkan keuntungan dalam kerja sama tersebut. Namaun dalam sistem ekonomi Islam bentuk kerja sama dalam kegiatan perekonomian menggunakan sistem bagi hasil untuk mendapatkan keuntungan, sehingga keuntungan yang didapat merupakan keuntungan bersama dan dibagi sesuai denga kesepakatan bersama.

Berdasarkan uraian tersebut di atas maka dalam artikel ini penulis akan mencoba untuk membahas hal-hal berkenaan dengan kerja sama atau investasi dengan menggunakan sistem bagi hasil. Agar pembahasan dalam makalah ini lebih spesifik, maka penulis akan lebih terfokus untuk membahas berkenaan dengan model-model investasi bagi hasil dalam ekonomi Islam.

\section{B. Pengertian Investasi dan Bagi Hasil}

Investasi adalah mengeluarkan sejumlah uang atau menyimpan uang pada sesuatu dengan harapan suatu saat mendapat keuntungan financial. Contoh investasi adalah pembelian berupa asset financial seperti obligasi, saham, asuransi. Dapat juga pembelian berupa barang seperti mobil atau property seperti rumah atau tanah.

1 M. Dawam Rahadrjo, “Ekonomi Islam: Apakah itu?" Makalah disampaikan dalam Seminar Ekonomi Islam di Jakarta pada Tanggal 21 Maret 2001, hlm. 3. 
Lebih luasnya investasi dapat berarti pembelian barang modal untuk produksi dalam suatu usaha misalnya pembelian mesin. Bahkan pemberian pendidikan dan pelatihan bagi karyawan yang membuat lebih mahir dalam bekerja bisa dikatakan sebagai investasi. Kesamaan dari semua investasi diatas adalah harapan memperoleh keuntungan (gain) di kemudian hari. ${ }^{2}$ Dalam buku yang lain disebutkan bahwa yang dimaksud dengan investasi adalah penggunaan dana atau modal untuk pembelian dimasa yang akan datang. ${ }^{3}$

Berdasarkan pengertian di atas maka dapat dipahami bahwa yang dimaksud dengan investasi adalah menyimpan sebagian dana yang disimpan baik dalam berupa barang atau berupa modal yang dijadikan modal usaha oleh orang lain. Hal tersebut bertujuan untuk mempersiapkan kebutuhan belanja dimasa yang akan datang. Dan juga bertujuan untuk mencari kelebihan nilai dari barang tersebut atau berupa keuntungan atas usaha yang dikelola oleh orang lain.

Bagi hasil menurut istilah adalah suatu sistem yang meliputi tata cara pembagian hasil usaha antara penyedia dana dan pengelola dana. ${ }^{4}$ Sedang menurut terminologi asing (Inggris) bagi hasil dikenal dengan profit sharring. Profit sharring dalam kamus ekonomi diartikan pembagian laba. Secara definitif profit sharring diartikan: "Distribusi beberapa bagian dari laba (profit) pada para pegawai dari suatu perusahaan". Lebih lanjut dikatakan, bahwa hal itu dapat berbentuk suatu bonus uang tunai tahunan yang didasarkan pada laba yang diperoleh pada tahuntahun sebelumnya, atau dapat berbentuk pembayaran mingguan atau bulanan. ${ }^{5}$

Bentuk-bentuk pembagian laba yang tidak langsung mencakup alokasi saham-saham (penyertaan) perusahaan pada para pegawai, dibayar melalui laba perusahaan, dan memberikan para pegawai opsi untuk membeli saham-saham sampai pada jumlah tertentu dimana yang akan datang pada tingkat harga sekarang, sehingga memungkinkan para pegawai memperoleh keuntungan baik dari pembagian deviden maupun setiap pertumbuhan dalam nilai saham yang dihasilkan dari peninghlm. 2 .

2 Enduardus Tandelilin, Portopolio dan investasi (Yoyakarta: Kanisius. 2010), 2.

3 Sapto Raharjo, Kiat Membangun Aset Kekayaan (Jakarta: Gramedia. 2006), hlm. 2.

${ }^{4}$ Ahmad Rofiq, Fiqih Kontekstual dari Normatif ke Pemaknaan Sosial (Yogyakarta: Pustaka Pelajar. 2004), hlm. 153.

5 Cristopher Pass, Kamus Lengkap Ekonomi (Jakarta: Erlangga. 1997), Cet. ke-2, hlm. 537. 
katan dalam kemampuan memperoleh laba. Jika dalam suatu perusahaan, maka perolehan bagian laba sering dianjurkan untuk meningkatkan tanggung jawab pegawai dan dengan demikian meningkatkan produktivitas. ${ }^{6}$

Pada mekanisme lembaga keuangan syari'ah, pendapatan bagi hasil ini berlaku untuk produk-produk penyertaan, baik penyertaan menyeluruh maupun sebagian-sebagian, atau bentuk bisnis korporasi (kerjasama). Pihak-pihak yang terlibat dalam kepentingan bisnis yang disebut tadi, harus melakukan transparansi dan kemitraan secara baik dan ideal. Sebab semua pengeluaran dan pemasukan rutin untuk kepentingan pribadi yang menjalankan proyek.

Keuntungan yang dibagihasilkan harus dibagi secara proporsional antara shahib al-mâl dengan mudharib. Dengan demikian, semua pengeluaran rutin yang berkaitan dengan bisnis mudharabah, bukan untuk kepentingan pribadi mudharib, dapat dimasukkan ke dalam biaya operasional. Keuntungan bersih harus dibagi antara shahib al-mâl dan mudharib sesuai dengan proporsi yang disepakati sebelumnya dan secara eksplisit disebutkan dalam perjanjian awal. Tidak ada pembagian laba sampai semua kerugian telah ditutup dan ekuiti shahib al-mâl telah dibayar kembali. Jika ada pembagian keuntungan sebelum habis masa perjanjian akan dianggap sebagai pembagian keuntungan di muka.

Inti mekanisme investasi bagi hasil pada dasarnya adalah terletak pada kerjasama yang baik antara shahib al-mâl dengan mudharib. Kerjasama atau partnership merupakan karakter dalam masyarakat ekonomi Islam. Kerjasama ekonomi harus dilakukan dalam semua lini kegiatan ekonomi, yaitu: produksi, distribusi barang maupun jasa. Salah satu bentuk kerjasama dalam bisnis atau ekonomi Islam adalah qirad atau mudlarabah. Qirad atau mudlarabah adalah kerjasama antara pemilik modal atau uang dengan pengusaha pemilik keahlian atau keterampilan atau tenaga dalam pelaksanaan unit-unit ekonomi atau proyek usaha. Melalui qirad atau mudlarabah kedua belah pihak yang bermitra tidak akan mendapatkan bunga, tetapi mendapatkan bagi hasil atau profit dan loss sharing dari proyek ekonomi yang disepakati bersama. ${ }^{7}$

6 Muhammad, Teknik Perhitungan Bagi Hasil di Bank Syari'ah (Yogyakarta: UII Press. 2001), hlm. 23.

7 Ibid., hlm. 24. 
Berdasarkan uraian di atas berkenaan dengan pengertian bagi hasil, maka dapat dipahami bahwa yang dimaksud dengan bagi hasil adalah pembagian keuntungan atas usaha atau bisnis yang dilakukan oleh dua pihak atau lebih setelah keuntungan tersebut dikurangi biaya operasional atas kegiatan usaha atau bisnis tersebut. Dan adapun proporsi pembagian keuntungan tersebut didasarkan pada kesepakatan antara para piahak yang melakukan kerja sama.

Penelitian Muchlis Yahya menyimpulkan bahwa bagi hasil merupakan variable paling signifikan dan memiliki koefisien paling tinggi dibanding variable-variabel lainnya untuk semua kelompok nasabah. Hanya saja bagi kelompok nasabah muslim yang hanya menabung di bank syariah memahami bagi hasil yang diterimanya bukan sematamata karena faktor ekonomi, tetapi karena lebih dibenarkan agama dan lebih adil. Akan tetapi bagi kelompok nasabah muslim yang menabung bersama-sama di bank syariah dan bank konvensional, dan kelompok nasabah non muslim memahami bagi hasil yang diterima karena lebih kompetitif dibanding dengan pendapatan bunga dari bank konvensional. ${ }^{8}$

Tarek dan Hassan melakukan penelitian tentang "survei literatur pembiayaan dan perbankan Islam (a comparative literature survey of Islamic finance and banking). Penelitian ini melibatkan variabel dependen pertumbuhan pembiayaan dan perbankan Islam, dan variabel independen reformasi struktural sistem keuangan konvensional, liberalisasi pergerakan modal, privatisasi, dan integrasi pasar-pasar keuangan global, serta inovasi produk-produk perbankan Islam. Dasar pemikiran yang digunakan dalam survei literatur ini adalah, bahwa pembiayaan Islami adalah sistem keuangan yang bertujuan membantu mencapai kemakmuran yang berkeadilan sosial sesuai dengan ajaran al-Qur'an. Pembiayaan syariah tidak dibenarkan untuk meraup return maksimal dari aset-aset keuangan berdasar kontrak eksploitatif ribawi (bunga/ usury), tetapi harus dijalankan dengan landasan profit and loss sharing. Penelitian ini dilakukan di Amerika Serikat, dan merupakan penelitian/ survei literatur terhadap penelitian-penelitian terdahulu. Oleh karenanya data yang digunakan adalah data sekunder.

Jalaluddin melakukan riset terhadap 80 lembaga keuangan di Sydney Australia. Teknik analisis data penelitian menggunakan analisis

8 Muchlis Yahya, "Perilaku Menabung di Perbankan Syariah di Jawa Tengah", dalam Disertasi pada Tahun 2011 di UNDIP Semarang Indonesia. 
faktor dan diskriminan berganda. Hasil penelitian menunjukkan 41,2\% lembaga keuangan mengindikasikan kesiapan mereka memberikan kredit berdasarkan bagi hasil. Dukungan bisnis merupakan motivasi utama kepada lembaga keuangan untuk menerapkan metode pembiayaan bagi hasil. Para responden menyatakan bahwa pembayaran bunga kadang-kadang menciptakan kesulitan bagi bisnis. Ketidak biasaan untuk bagi resiko dengan kreditur merupakan alasan-alasan utama terhadap ketidak siapan lembaga keuangan untuk memberi kredit berdasarkan bagi hasil. Pertumbuhan permintaan dana merupakan faktor yang paling signifikan dalam membedakan antara perusahaanperusahaan keuangan yang siap memberikan kredit berdasarkan bagi hasil. Pada tahun yang sama dengan teknik dan metode yang persis, tetapi dengan responden berbeda Jalaluddin melakukan penelitian terhadap 385 bisnis kecil di Sydney Australia. Hasil penelitian menunjukkan, bahwa 59,5\% perusahaan bisnis kecil tertarik menggunakan metode pembiayaan bagi hasil. Dukungan bisnis merupakan motivasi utama di dalam menerapkan metode pembiayaan bagi hasil. ${ }^{9}$

Gerrard dan Cunningham melakukan penelitian terhadap 190 responden muslim dan non-muslim di Singapura dengan kesimpulan bahwa nasabah non muslim meletakkan faktor tingkat nilai bagi hasil sebagai variabel utama memanfaatkan bank syariah. Secara lebih luas Gerrard menyimpulkan bahwa sikap dan pandangan Muslim dan non Muslim mengenai motivasi religius dan profitabilitas adalah berbeda. Layanan yang cepat dan efisien serta kerahasiaan merupakan faktorfaktor utama dalam memilih layanan bank. Nasabah non-muslim memberi peringkat tertinggi pada return berupa nilai bagi hasil yang bersaing dengan pendapatan karena bunga. Sedangkan bagi nasabah muslim profitabilitas nilai bagi hasil bukan faktor utama pemanfaatan bank syariah. ${ }^{10}$

Humayon dan Presley melakukan penelitian tentang Lack of Profit Loss Sharing in Islamic Banking: Management and Control Imbalances. Variabel dependennya adalah penerapan profit and loss sharing pada perbankan syariah dan variabel independennya terdiri dari aplikasi

9 Jalaluddin, A., "Attitudes of Australian Financial Institutions towards Lending on the Profit/Loss Sharing Method of Finance". Chapter in Attitudes of Australian Small Business Firms and Financial Institutions towards the Profit/Loss Sharing Method of Finance. PhD Dissertation, 1999 at University of Wollongong.

10 Gerrard, P and Cunningham J, "Islamic Banking: A Study in Singapore." International Journal of Bank Marketing 15(6), 2011: 204-216. 
manajemen dan fungsi kontrol. Teori dasar yang digunakan dalam penelitian ini adalah PLS (Profit Loss Sharing) atau sharing resiko/bagi rugi-laba dengan dua model utama, yaitu Mudharabah dan Musyarakah. Penelitian ini dilakukan di Inggris. Data dianalisis dengan teknik analisis deskriptif. Penelitian ini melahirkan kesimpulan:11

1. Penerapan manajemen dan kontrol menjadi titik penting bagi penerapan model PLS pada perbank-an syariah;

2. Penghindaran intensif dari melakukan kecurangan akan mendorong penerapan model PLS pada perbankan syariah;

3. Praktek penyembunyian informasi berpengaruh negatif terhadap penerapan model PLS pada perbankan syariah; dan

4. Sistem yang tidak memungkinkan berkembangnya instrumeninstrumen bagi hasil yang terbuka dan efisien berpengaruh negatif terhadap penerapan model PLS pada perbankan syariah.

Tahun 2005, Okumus melakukan penelitian terhadap 161 nasabah bank Islam di Turki dengan analisis deskriptif. Hasilnya menunjukkan, bahwa motivasi sekunder pemanfaatan bank Islam adalah dilandasi oleh prinsip bebas bunga yang diterapkan dengan model nisbah bagi hasil. Sebagian besar nasabah mengetahui produk dan jasa Islam, tetapi tidak mengetahui teknik-teknik pembiayaan Islam. Lebih dari $90 \%$ responden merasa puas dengan jasa dan produk yang ditawarkan bank Islam. ${ }^{12}$

Keharaman bunga dalam syariah membawa konsekuensi adanya penghapusan bunga secara mutlak. Teori PLS dibangun sebagai tawaran baru di luar sistem bunga yang cenderung tidak mencerminkan keadilan (injustice/dzalim) karena memberikan diskriminasi terhadap pembagian resiko maupun untung bagi para pelaku ekonomi. Principles of Islamic finance di bangun atas dasar larangan riba, larangan gharar, tuntunan bisnis halal, resiko bisnis ditanggung bersama, dan transaksi ekonomi berlandaskan pada pertimbangan memenuhi rasa keadilan. ${ }^{13}$

Uraian di atas menunjukkan bahwa investasi dengan mengguna-

11 Humayon A. Dar and John R. Presley (2001), "Lack of Profit Loss Sharing in Islamic Banking: Management and Control Imbalances”, Economic Research Paper No. 00/24, Centre for International, Financial and Economic Research.

12 Okumus, H. "Interest-Free Banking in Turkey: A Study of Customer Satisfactin and Bank Selection Criteria." Journal of Economic Cooperation 26(4), 2005: 51-86.

13 Alsadek H. Gait, Andrew C. Worthington (2006), An Empirical Survey of Individual Consumer, Busness Firm and Financial Institution Attitudes towards Islamic Methods, School of Accounting \& Finance University of Wollongong, Wollongong NSW 2522 Australia, JEL Classification: D12; G20; Z12. 
kan sistem bagi hasil memiliki kelebihan dibandingkan dengan sistem bunga. Investasi bagi hasil menciptakan keseimbangan antara pemilik modal dan pengelola modal dalam hal pembagian keuntungan dan resiko; menciptakan suatu tatanan masyarakat yang adil, tidak terjadi kezaliman juga terwujudnya pemerataan. Semua hal tersebut merupakan tujuan ajaran Islam dalam mewujudkan tatanan kehidupan manusia di muka bumi ini. Namun perlu diketahaui pula bahwasannya ekonomi Islam juga mempunyai tujuan yang tidak kalah pentingnya, yaitu meningkatkan aspek spritual. Karena ekonomi Islam hadir bukan hanya sekedar untuk mendapatkan kebahagiaan di dunia saja melainkan sekaligus mendapatkan kebahagiaan di akhirat (falâh).

\section{Model Investasi Bagi Hasil dalam Ekonomi Mikro Islam}

Macam-macam bagi hasil sangat banyak. Namun secara umum prinsip bagi hasil dalam perbankan syari'ah dapat dilakukan dalam empat akad utama yakni al-musyârakah, al-mudlârabah, al-muzâra'ah, dan al-musâqah. Dengan demikian prinsip yang paling banyak dipakai adalah al-musyârakah dan al-mudlârabah. ${ }^{14}$

Teori bagi hasil (profit and loss sharing) dikembangkan dalam dua model, yakni model mudharabah dan musyarakah. Model Mudharabah merujuk pada bentuk kerjasama usaha antara dua belah pihak. Pihak pertama (shahib al-mâl) menyediakan seluruh modal, sedangkan pihak lainnya menjadi pengelola dana (mudlârib). Model musyarakah adalah akad kerjasama antara dua pihak atau lebih untuk menjalankan suatu usaha tertentu. Masing-masing pihak memberikan kontribusi dana dengan kesepakatan keuntungan dan resiko ditanggung bersama sesuai dengan kesepakatan. ${ }^{15}$

\section{Musyarakah}

Musyarakah atau sering disebut syarikah mempunyai arti: sekutu atau teman sepersekutuan, perkumpulan, perserikatan. ${ }^{16}$ Syirkah secara etimologi berarti: al-ikhtilath mempunyai arti: campur atau percam-

14 Muhamad Syafi'I Antonio, Bank Syari'ah dari Teori ke Praktek (Jakarta: Gema Insani Press, 2001), hlm. 90. Lihat juga Helmi Karim, Fiqih Mumalah (Jakarta: PT. Raja Grafindo Persada. 1996).

15 Zainul Arifin, Memahami Bank Syariah: Lingkup, Peluang, Tantangan dan Prospek (Jakarta: AlvaBet. 2000).

16 Mahmud Yunus, Kamus Arab - Indonesia (Jakarta: Yayasan Penyelenggara dan Penterjemah Al-Qur'an. 1973), hlm. 196. 
puran. ${ }^{17}$ Maksud dari percampuran disini adalah seorang mencampurkan hartanya dengan harta orang lain sehingga antara bagian yang satu dengan bagian yang lainya sulit untuk dibedakan lagi.

Adapun secara terminologi para ahli fikih adalah akad antara orang-orang yang berserikat dalam modal maupun keuntungan. ${ }^{18}$ Hasil keuntungan dibagihasilkan sesuai dengan kesepakatan bersama di awal sebelum melakukan usaha. Sedang kerugian ditanggung secara proposional sampai batas modal masing-masing. ${ }^{19}$

Akad Syirkah diperbolehkan menurut Ulama' Fikih, berdasarkan Al-quran dan Al-hadits. Dalam Al-qur'an Allah SWT berfirman dalam QS. Shâd ayat 24 sebagai berikut:

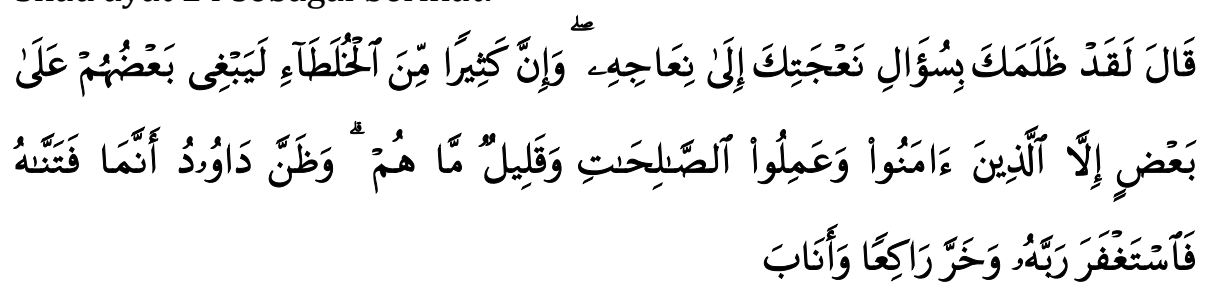

Daud berkata: "Sesungguhnya Dia telah berbuat zalim kepadamu dengan meminta kambingmu itu untuk ditambahkan kepada kambingnya. dan Sesungguhnya kebanyakan dari orang-orang yang berserikat itu sebahagian mereka berbuat zalim kepada sebahagian yang lain, kecuali orang-orang yang beriman dan mengerjakan amal yang saleh; dan Amat sedikitlah mereka ini". dan Daud mengetahui bahwa Kami mengujinya; Maka ia meminta ampun kepada Tuhannya lalu menyungkur sujud dan bertaubat.

Ayat di atas menunjukkan perkenan dan pengakuan Allah akan adanya perserikatan dalam kepemilikan harta. dalam surat Shâd Perserikatan terjadi atas dasar akad (ikhtiyary). ${ }^{20}$ Selain dalam Al Quran dasar hukum musyarakah juga terdapat dalam salah satu hadits Qudsi yang menyatakan sebagai berikut :

${ }^{17}$ Abdurrahman Al-Jaziri, Kitab al-fiqh 'Ala Mazhab Al-arba'ah (Lebanon: Dar Alkutub Al Ilmiyyah. 1990), juz III, hlm. 60.

18 Ibnu Rusyd, Bidayah al-Mujtahid, terj. Imam Ghozali Said, Analisa Fiqih Para Mujtahid (Jakarta: Pustaka Amani. t.t.), hlm. 143-153.

19 Zainul Arifin, Memahami Bank Syari'ah (Jakarta: Alvabet. 2000), hlm. 203.

${ }^{20}$ Muhammad Syafi'I Antonio, Bank Syari'ah. hlm. 91. 


\section{عن ابى هريرة رضي الله عنه قال : قال رسول الله صلى الله عليه وسلم :قال الله تعالى :انا ثالث الشريكين ما لم يخن احدهما صاحبه فاداخانه خرجت من يينهما (رواه ابو داود بسند صحيح)}

Dari Abi Hurairah r.a. ia berkata: Rasulullah SAW bersabda: Allah SWT berfirman: Aku adalah pihak ketiga dari dua orang yang sedang berserikat selama salah satu dari keduanya tidak khianat terhadap saudaranya (temanya). Apabila diantara mereka ada yang saling berkhianat, maka Aku akan keluar dari mereka (H.R Abu Dawud). ${ }^{21}$

Hadits di atas menunjukan bahwa Rahmat Allah SWT tercurahkan atas dua pihak yang sedang berkongsi selama mereka tidak melakukan penghianatan, manakala berkhianat maka bisnisnya akan tercela dan keberkahanpun akan sirna dari padanya. Berdasarkan keterangan Alquran dan Hadits Rasul tersebut diatas pada prinsipnya seluruh Fuqaha' sepakat menetapkan bahwa hukum syirkah adalah Mubah, meskipun Mereka memperselisihkan keabsahan beberapa jenis hukum syirkah. ${ }^{22}$

\section{Mudharabah}

Mudharabah mempunyai arti memukul atau berjalan. Pengertian memukul atau berjalan ini lebih tepatnya adalah proses seseorang memukulkan kakinya dengan menjalankan usaha. ${ }^{23}$ Pengertian secara bahasa ini memiliki dua relevansi antara keduanya, yaitu: pertama karena yang melakukan usaha ('amil) yadhrib fil ardhi (berjalan dimuka bumi) dengan bepergian padanya untuk berdagang, maka ia berhak mendapatkan keuntungan karena usaha dan kerjanya. Seperti firman Allah SWT :" Dan sebagian orang-orang yang lain berjalan di muka bumi mencari sebagian karunia Allah". Kedua, karena masing-masing orang yang bersyarikat dalam keuntungan. ${ }^{24}$

21 Imam Taqyudin Abu Bakar bin Muhammad Alhusaini, Kifayatul Akhyar, Terj. Syarifuddin Anwar, Kifayatul Akhyar Kelengkapan Orang Shaleh (Surabaya: Bina Iman. 1995), hlm. 629-630.

22 Wahbah Az-Zuhaili, Al-Fiqh Al-Islam Wa Adillatuhu (Beirut: Daar Fikr. t.th.), juz IV, hlm. 792-793.

23 Muhammad Syafi'I Antonio, Bank Syari'ah Suatu Pengenalan Umum (Jakarta: Tazkia Institute. 1999), hlm. 135.

${ }^{24}$ Muhammad, Bank Syariah. hlm. 56. 
Mudharabah termasuk macam syarikat yang paling lama dan paling banyak dipakai dalam masyarakat, dan telah dikenal oleh bangsa Arab sebelum Islam serta telah dijalankan oleh Rasulullah SAW sebelum kenabiannya sebagaimana telah diakui dan disetujui Nabi SAW setelah kenabiannya. Penamaan macam syarikat ini dengan (mudlarabah) adalah menurut umat Islam di Iraq dan mereka juga menamainya dengan (Mu'amalah) dikatakan; 'aamaltu rajulan mu'amalatan yang berarti adalah saya memberinya uang untuk mudlarabah. ${ }^{25}$ Para penduduk Hijaz menamainya dengan Qiradh yaitu berasal dari fiil madhi ) qardh yang berarti al-qath'u atau pemotongan. Hal itu karena pemilik harta memotong dari sebagian hartanya sebagai modal dan menyerahkan hak pengurusanya kepada orang yang mengelolanya dan pengelola memotong untuk pemilik bagian dari keuntungan sebagai hasil dari usaha dan kerjanya.

Adapun dasar hukum pelaksanaan mudharanah adalah firman Allah dalam Surat Al Hadid ayat 11:

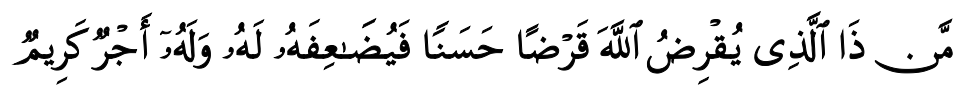

Siapakah yang mau meminjamkan kepada Allah pinjaman yang baik, Maka Allah akan melipat-gandakan (balasan) pinjaman itu untuknya, dan Dia akan memperoleh pahala yang banyak.

\section{Pandangan Tokoh Ekonomi Islam Terhadap Model Investasi Bagi Hasil}

Menurut Faim Khan, sebagaimana para ahli ekonomi Islam lainnya menguatkan teori bahwa Islam dengan ajaran yang dibawanya dan institusi-institusi yang dimunculkannya, memiliki kontribusi positif bagi pertumbuhan dan pembangunan ekonomi. Misalnya; zakat, larangan riba serta pola kemitraan dalam musyarakah/mudharabah, dapat menjadi strategi riil untuk meningkatkan produktivitas masyarakat.26 Bahkan Maya Shatzmiller dalam artikelnya Economic Performance and Economic Growth in the Early Islamic World dengan menelaah peran instiusi-institusi Islam pada periode-periode pertumbuhan ekonomi menyatakan bahwa ada kejelasan indikator yang menunjukkan bahwa aturan ekonomi Islam dan institusi-institusinya mendukung dan sama

\section{Ibid.}

26 Editor, "Biodata of Dr. Fahim Khan - IRTI Publication", dalam http://www.irtipms.org/Fahim\%20Khan_E.asp, diakses tanggal 05 Juni 2015. 
sekali tidak menghalangi pertumbuhan ekonomi. Artikel Maya membantah Greif dan Timur Kuran yang menganggap aturan dan institusi Islam tidak berhasil mematerialisasikan pertumbuhan ekonomi. ${ }^{27}$

Fahim Khan menjelaskan bahwa ekonomi Islam memiliki kelebihan dengan mengunakan sistem bagi hasil dalam uapaya membangun perekonomian, ia mengambil contoh kasus di Pakistan dan Indonesia sebagai negara dengan kondisi ekonomi berlimpah tenaga kerja. Di negara-negara ini orang menganggur bukan karena tidak mau bekerja, tetapi karena mereka tidak mendapatkan pekerjaan sesuai apa yang mereka bisa kerjakan. Dengan pendapatan perkapita yang masih rendah, tentu orang-orang ini memiliki keinginan kuat untuk meningkatkan taraf kehidupan yang lebih baik dengan bekerja. Ketika tidak ada penawaran pekerjaan, mereka tidak dapat menjalankan bisnis atau usaha mandiri karena tidak memiliki modal sendiri. Pada umumnya Negara dengan surplus tenaga kerja, sebagian besar sumber daya manusianya tidak memiliki modal. Mereka membutuhkan pinjaman modal jika ingin melakukan usaha mandiri. ${ }^{28}$

Strategi membuka peluang kewirausahaan bagi surplus sumber daya manusia memerlukan beberapa prasyarat sebagai berikut:

1. Ketersediaan modal yang diperlukan oleh surplus tenaga kerja dalam memulai usaha mandiri;

2. Adanya sistem yang dapat menjamin pembagian risiko yang adil antara pemilik modal dan pengusaha; dan

3. Adanya sistem penjaminan sosial yang dapat menopang dan membimbing kehidupan pelaku usahahingga mereka meraih kesuksesan berwiraswasta. ${ }^{17}$

Ketiga prasyarat tersebut dipakai Fahim Khan untuk membandingkan sistem konvensional berbasis bunga dengan sistem ekonomi Islam berbasis bagi hasil dalam mendukung strategi menciptakan peluang kewirausahaan. Sistem ekonomi non-Islam yang berbasis bunga dinilai tidak berhasil mewujudkan prasyarat-prasyarat di atas terutama di negara-negara berkembang yang berpenduduk padat. Sistem berbasis bunga dipandang tidak menyediakan modal yang dibutuhkan oleh calon

27 Maya Shatzmiller, "Economic Performance and Econom ic Growth in the Early Islamic World", Journal of the Economic andSocial History of the Orient 54, 2011: 132184.

28 Editor, "Biodata of Dr. Fahim Khan - IRTI Publication", dalam http://www.irtipms.org/Fahim\%20Khan_E.asp, diakses tanggal 05 Juni 2015, hlm. 198-199. 
wirausahawan potensial yang akan memulai usaha. Sistem ini lebih tertarik untuk membiayai usaha mapan yang dapat memastikan terhindar dari kredit macet dan berbagai resiko pembiayaan. Pengajuan pembiayaan oleh orang baru akan memulai usaha biasanya menuntut dipenuhinya persyaratan yang sulit termasuk jaminan yang kadang tidak dapat dipenuhi oleh calon pelaku usaha. Dalam kondisi ini tentu ia akan lebih memilih untuk mencari kerja berupah tetap dari pada melakukan usaha mandiri yang sulit dan beresiko. ${ }^{18}$

Dukungan Fahim Khan terhadap ekonomi Islam lebih pada dukungan formalitas pemberlakuan fikih muamalah dari pada prinsip atau nilai ekonomi Islam dengan aplikasi yang lebih efektif komprehensif. Penekanan pada sisi formalitas ini nampak pada apa yang ia maksudkan dengan bagi hasil. Ia hanya mempromosikan bagi hasil atau kemitraan dengan format mudarabah atau musyarakah. Ia tidaka mencoba mengimplementasikannya dengan lebih luas dan berimbang. Konsep Fahim Khan masih kental normatifnya. Ia membuat batasan hitam putih antara sewa dengan kemitraan. Fahim Khan kurang memperhatikan inovasi aplikasi nilai kemitraan sacara fungsional. Ia masih berkutat pada normativitas syirkah dan mudlarabah. Padahal di Jepang yang bukan negara Islam saja berhasil mengartikulasikan prinsip kemitraan ini pada bidang hubungan antara pekerja dan perusahaan. Prinsip sewa telah diramu dengan prinsip kemitraan.

Gerakan produktivitas Jepang menunjukkan bagaimana kejasama atau bagi hasil diimplementasikan di antara pekerja dan yang memperkerjakan. Berbeda dengan ilmu ekonomi klasik yang memandang tenaga kerja manusia sebagai bagian dari unsur pokok produksi di samping modal dan tanah, konsep produktivitas Jepang menekankan bahwa bahwa manusia secara alamiah membuat barang dan jasa yang diperlukan untuk hidup. Sedangkan tanah, modal dan teknologi adalah alat untuk produksi. Manusia harus memainkan peranan utama dalam memanfaatkan nilai guna dari ketiga unsur tersebut. Perusahaan perlu memperhatikan dimensi sosial kerjasama kerja sama antar tenaga kerja. Tenaga kerja harus dipandang sebagai prioritas di atas modal, tanah dan teknologi. Di sini, tenaga kerja merupakan bentuk keunikan tingkah laku dari jenis manuisia dan meningkatkan produktivitas dengan memperbaiki kondisi kerja merupakan landasan bagi pengisisan hidup secara 
baik serta memberikan "arti" bagi kehidupan manusia. ${ }^{29}$

Strategi Fahim Khan belum sampai kepada kendala yang dihadapi yang secara empiris terjadi ketika digalakkan usaha berbasis bagi hasil. Tidak sedikit orang yang tertarik dan terdorong melakukan usaha tetapi tidak mencapai kesuksesan yang diharapkan bukan karena tidak ada peluang tetapi karena ada faktor lain yang lebih mendasar. Salah satunya diungkap oleh Musa Asy'arie, dalam pembinaan pembinaan industri kecil dan menengah, banyak menghadapi masalah terkait keterbatasan dalam akses pasar, sumber-sumber pembiayaan dan permodalan, penguasaan teknologi dan informasi, keterbatasan dalam organisasi dan manajemen, serta pengembangan jaringan usaha dan kemitraan antara pelaku ekonomi yang ada. Di atas itu semua Musa Asy'ari mengungkap adanya persoalan mendasar yang mengurung pelaku usaha sehingga sulit untuk keluar dari banyak masalah tersebut. Meski banyak bantuan tersedia dan ada niat yang besar dari dalam diri mereka namun terasa berat untuk melangkah maju. Persoalan mendasar yang mengurung ini lebih bersifat kultural, yaitu sistem nilai budaya yang telah membentuk kepribadian pelaku usaha yang sudah berjalan puluhan tahun. Sistem nilai budaya ini mempengaruhi cara pelaku usaha tersebut menjalankan usaha (manajemen), seperti cara dalam bekerja, menghadapi mitra bisnisnya, menangani karyawan, mengelola uang, menggunakan keuntungan, menghadapi pesaing dan bertahan menghadapi perubahan dan menghadapi krisis. ${ }^{30}$

Sedangkan menurut Choudhury berkenaan dengan pembahsan ekonomi Islam dalam hal investasi bagi hasi sebagaimana diungkapkan Muhammad Muflih dalam jurnalnya: Pengendalian Inflasi Studi Komparasi antara Ekonomi Konvensional dan Ekonomi Islam, Choudhury menemukan keseimbangan umum dalam struktur ekonomi makro islami. Choudhury menunjukkan kerangka mekanisme bagi hasil tersebut sebagai alternatif dari peniadaan bunga, mampu mengkonseptualkan kembali keseimbangan kurva $I S$ dan $L M$ islami, yang pada akhirnya memakmurkan sektor investasi. Lalu, pengendalian konsumsi, zakat, pajak kekayaan, dan tabungan juga dapat mengantarkan kondisi ekonomi makro yang seimbang sehingga terjadi alur yang proporsional

29 J. Ravianto, Orientasi Produktivitas dan Ekonomi Jepang, Apa yang Harus Dilakukaan Indonesia? (Jakarta: UI Press. 1986), hlm. 32.

${ }^{30}$ Musa Asy'arie, Keluar dari Krisis Multi Dimensi (Yogyakarta: LESFI. 2001), hlm. 124. 
dalam aliran uang, dan terjadi pemerataan di tingkat masyarakat. ${ }^{31}$

Berdasarkan urain tersebut di atas berkenaan dengan model investasi bagi hasil dalam ekonomi mikro Islam dan model investasi bagi hasil menurut para tokoh ekonomi Islam saat ini, maka dapat dipahami bahwasannya model investasi bagi hasil yang berkembang adalah dalam dua model yaitu musyarakah dan mudharabah. Pandangan para tokoh ekonomi Islam berkenaan dengan kedua model investasi bagi hasi tersebut, mereka menjelaskan bahwa dalam rangka meningkatkan pertumbuhan dan pembangunan ekonomi masyarakat model investasi tersebut sanagt dibutuhakan dan mesti diaplikasikan. Karena model investasi bagi hasil merupakan kerangka yang berfungsi sebagai alternatif dari peniadaan bunga, dan mampu mengkonseptualkan kembali keseimbangan kurva IS dan $L M$ Islami.

\section{E. Aplikasi Investasi Bagi Hasil dalam Kehidupan Sehari-hari}

Aplikasi ivestasi bagi hasil sebenarnya sudah dilaksanakan dalam kehidupan sehari-hari. Dimana dalam kehidupan sehari-hari terutama seseorang yang tinggal diperkotaan sementara ia memepunyai lahan baik berupa pesawahan maupun berupa ladang. Karena dengan kesibukannya bekerja di perkotaan sehingga ia tidak ada waktu untuk mengelola lahan tersebut. Akhirnya ia bekerja sama dengan seorang petani yang ada diperkampungan yang dekat dengan lokasi lahannya tersebut. Kerja sama yang dibangun antara pemilik tanah dengan pengelola tanah biasa kerja sama secara kekeluargaan. Di mana sipengelola diberikan kewenangan secara luas untuk mengelola lahan tersebut. Dan apabila ada hasil dari lahan tersebut, maka dibagi dua antara pemilik lahan dengan pengelola sesuai dengan kesepakatan. Jadi investasi bagi hasil sebenarnya dalam kehidupan sehari-hari sebenarnya sudah banyak dilakukan sebagaimana telah diuraikan. Namun pada umumnya masyarakat tidak mengetahui akan hal itu, yang penting ia mengelola lahan orang lain dan orang yang memiliki lahan juga hanya mengetahui bahwa lahannya dikelola oleh orang lain. Padahal konsep tersebut merupakan penerapan dari sebagaian sistem ekonomi Islam.

Penerapan investasi bagi hasil seperti diuraikan di atas hanya bersifat individual, sehingga tidak semua orang dapat menikmatinya.

31 Masudul Alam Choudhury, Contribution to Islamic Economic Theory a Study in Social Economics (New York: St. Martin's Press. 1986), hlm. 172-187. Dalam Jurnal Reforma, Vol. 1, Tahun VII, No. 15, Maret 2009, Muhammad Muflih, Pengendalian Inflasi Studi Komparasi antara Ekonomi Konvensional dan Ekonomi Islam. 
Dan besar harapan bahwa investasi bagi hasil yang dikembangkan oleh lembaga perbankan sebagai salah satu intitusi lembaga keuangan mampu mengembangkan investasi bagi hasil pada sektor pertanian, peternakan dan perikanan lebih besar dibandingkan investasi bagi hasil pada sektor indutri. Karena secara geografis bahwa sumber daya alam negara indonesia yang mesti dimanfaatkan secara maksimal adalah sektor-sektor tersebu. Dengan harapan seiring perkembangan ekonomi Islam yang diwakili oleh lembaga perbankan syariah mampu menciptakan masyarakat yang adil dan sejahtera secara menyeluruh. Dan keadaan masyarakat seperti itulah yang menjadi tujuan ajaran Islam.

Adapun penerapan investasi bagi hasil di lembaga keuangan berupa perbankan biasanya dilaksanakan sebagai mana berikut:

1. Mudharabah biasanya diterapkan pada produk-produk pembiayaan dan pendanaan. Pada sisi penghimpunan dana mudharabah diterapkan pada:

a. Tabungan berjangka, tabungan yang dimaksudkan untuk tujuan khusus, seperti tabungan haji, tabungan kurban, deposito biasa; dan

b. Deposito spesial (special investment), dimana dana yang dititipkan nasabah khusus untuk bisnis tertentu, misalnya mudharabah saja atau ijarah saja.

Adapun pada sisi pembiayaan, mudharabah diterapkan untuk:

1) Pembiayaan modal kerja, seperti pembiayaan modal kerja perdagangan dan jasa;

2) Investasi khusus, disebut juga dengan mudharabah muqayyadah, dimana sumber dana khusus dengan penyaluran yang khusus dengan syarat-syarat yang telah ditetapkan oleh shahib al-mal (bank). ${ }^{32}$

2. Musyarakah dalam perbankan syariah dapat dijumpai pada pembiayaan-pembiayaan seperti:

a. Pembiayaan Proyek

Musyarakah biasanya diaplikasikan untuk pembiayaan proyek dimana nasabah dan bank sama-sama menyediakan dana untuk membiayai proyek tersebut, dan setelah proyek itu selesai nasabah mengembalikan dana tersebut bersama bagi hasil yang telah disepakati untuk bank.

b. Modal Ventura

32 Muhammad Syafi'i Antonio, Bank Syariah. hlm. 95. 
Pada lembaga keuangan khusus yang dibolehkan melakukan investasi dalam kepemilikan perusahaan, musyarakah diaplikasikan dalam skema modal ventura. Penanaman modal dilakukan untuk jangka waktu tertentu dan setelah itu bank melakukan divestasi atau menjual bagian sahamnya, baik secara singkat maupun bertahap. ${ }^{33}$

Berdasarkan uraian di atas mengenai implementasi model investasi bagi hasil ekonomi Islam dalam dalam kehidupan sehari-hari maka dapat dipahami, bahwa penerapannya sudah dilakukan, namun masyarakat belum mengetahui bahwa hal tersebut merupakan bagian dari ekonomi Islam dan berupa tuntunan dari ajaran Islam. Karena tidak terstruktur dengan baik, maka hanya dapat dilakukan secara individu saja sehingga tidak berkembang dan berpengaruh secara besar terhadap perkembanagn ekonomi masyarakat. Pada lembaga lembaga keuangan, untuk saat ini model investasi yang digunakan oleh lembaga keuangan baru pada model investasi dalam bentuk musyarakah dan mudharabah. Adapaun bentuk penerapan kedua model investasi tersebut yaitu dalam bentuk pembiayaan dan penghimpunan dana dari nasabah. Adapaun dalam bentuk investasi musaqah dan muzara'ah untuk saat ini belum banyak dilakukan pada lembaga keuangan. Padahal negara Indonesia merupakan suatu negara agraris. Investasi bagi hasil seharusnya lebih banyak dilakukan pada pembiayaan sektor pertanian, peternakan dan perikanan. Namun kenyataan sekarang ini, lebih banyak dilakukan pada sektor industri.

\section{F. Penutup}

Investasi adalah menyimpan sebagian dana yang disimpan baik dalam berupa barang atau berupa modal yang dijadikan modal usaha oleh orang lain. Hal tersebut bertujuan untuk mempersiapkan kebutuhan belanja dimasa yang akan datang dan mencari kelebihan nilai dari barang tersebut atau berupa keuntungan atas usaha yang dikelola oleh orang lain. Sedangkan yang dimaksud dengan bagi hasil adalah pembagian keuntungan atas usaha atau bisnis yang dilakukan oleh dua pihak atau lebih setelah keuntungan tersebut dikurangi biaya operasional atas kegiatan usaha atau bisnis tersebut. Adapun proporsi pembagian keuntungan tersebut didasarkan pada kesepakatan antara

33 https://ayahaca.wordpress.com/2011/06/06/34/, diakses tanggal 20 Mei 2015. 
para piahak yang melakukan kerja sama dan didasarkan pada prinsip tolong menolong diantara sesama.

Model atau macam-macam investasi bagi hasil dalam ekonomi mikro Islam sangat banyak. Secara umum prinsip bagi hasil dalam perbankan syari'ah dapat dilakukan dalam empat akad utama yakni almusyârakah, al-mudlârabah, al-muzâra'ah, dan al-musâqah. Sungguhpun demikian prinsip yang paling banyak dipakai adalah al-musyârakah dan al-mudlârabah. Meskipun pada kenyataannya model investasi yang sudah berjalan di lembaga keuangan syariah belum murni seratus persen syar'i. Hal itu terlihat masih banyaknya penerapan model investasi bagi hasil dalam ekonomi Islam yang menitikberatkan kepada aspek keuntungan secara individu atau kelompok yang lebih dominan, ketimbang aspek tolong menolong, pemerataan dan kesejahteraan masyarakat banyak.

Model investasi bagi hasil sangat dibutuhakan dan mesti diaplikasikan dalam rangka meningkatkan pertumbuhan dan pembangunan ekonomi masyarakat, karena merupakan kerangka yang berfungsi sebagai alternatif dari peniadaan bunga, dan mampu mengkonseptualkan kembali keseimbangan kurva $I S$ dan $L M$ Islami.

\section{DAFTAR PUSTAKA}

Al-Husaini, Imam Taqyudin Abu Bakar bin Muhammad. 1995. Kifayatul Akhyar, Terj. Syarifuddin Anwar, Kifayatul Akhyar Kelengkapan Orang Shaleh. Surabaya: Bina Iman.

Al-Jaziri, Abdurrahman. t.t.h. Al-fikih 'ala Mazhab al-Arba'ah. Lebanon: Dar Al-Kutub Al-'Ilmiyyah.

Alsadek H. Gait, Andrew C. Worthington. 2006. "An Empirical Survey of Individual Consumer, Busness Firm and Financial Institution Attitudes towards Islamic Methods". School of Accounting \& Finance University of Wollongong, Wollongong NSW 2522 Australia, JEL Classification: D12; G20; Z12.

Arifin, Zainul. 2000. Memahami Bank Syariah: Lingkup, Peluang, Tantangan dan Prospek. Jakarta: AlvaBet. 
Asy'arie, J. R. Musa. 2001. Keluar dari Krisis Multi Dimensi. Yogyakarta: LESFI.

Az- Zuhaili, Wahbah. t.th. al-fikih al-Islam Wa Adillatuhu. Beirut: Dar alFikr.

Choudhury, Masudul Alam. 1986. Contribution to Islamic Economic Theory a Study in Social Economics. New York: St. Martin's Press.

Editor. 2015. "Biodata of Dr. Fahim Khan-IRTI Publication". dalam http://www.irtipms.org/Fahim\%20Khan_E.asp, diakses tanggal 05 Juni 2015.

Humayon A. Dar and John R. Presley. 2001. "Lack of Profit Loss Sharing in Islamic Banking: Management and Control Imbalances", Economic Research Paper No. 00/24, Centre for International, Financial and Economic Research.

Karim, Helmi. 1996. Fikih Mumalah. Jakarta: PT. Raja Grafindo Persada.

Muflih, Muhammad. 2009. "Pengendalian Inflasi Studi Komparasi antara Ekonomi Konvensional dan Ekonomi Islam". dalam Jurnal Reforma, Vol. 1, Tahun VII, No. 15, Maret 2009.

Muhammad. 2001. Teknik Perhitungan Bagi Hasil di Bank Syari'ah. Yogyakarta: UII Press.

Okumus, H. 2005. "Interest-Free Banking in Turkey: A Study of Customer Satisfactin and Bank Selection Criteria". Journal of Economic Cooperation 26.

Pass, Cristopher. 1997. Kamus Lengkap Ekonomi. Jakarta: Erlangga.

Rahadrjo, M. Dawam. 2001. “Ekonomi Islam: Apakah itu?” dalam Makalah Seminar Ekonomi Islam di Jakarta.

Raharjo, Sapto. 2006. Kiat Membangun Aset Kekayaa. Jakarta: Gramedia.

Rofiq, Ahmad. 2004. Fikih Kontekstual dari Normatif ke Pemaknaan Sosial. Yogyakarta: Pustaka Pelajar.

Rusyd, Ibnu. 1995. Bidayah al-Mujtahid. terj. Imam Ghozali Said, Analisa Fikih Para Mujtahid. Jakarta: Pustaka Amani.

Shatzmiller, Maya. 2011. "Economic Performance and Econom ic Growth in the Early Islamic World". Journal of the Economic andSocial 
History of the Orient 54.

Syafi'i Antonio, Muhamad. 1999. Bank Syari'ah Suatu Pengenalan Umum. Jakarta: Tazkia Institute.

Syafi'i Antonio, Muhamad. 2001. Bank Syari'ah: Dari Teori ke Praktek. Jakarta: Gema Insani Press.

Tandelilin, Enduardus. 2010. Portopolio dan Investasi. Yoyakarta: Kanisius.

Yahya, Muchlis. 2001. "Perilaku Menabung di Perbankan Syariah di Jawa Tengah”. Disertasi UNDIP Semarang Indonesia.

Yunus, Mahmud. 1973. Kamus Arab-Indonesia. Jakarta: Yayasan Penyelenggara dan Penterjemah Al-Qur'an. 